\title{
Reducing Prison Sentencing through Pre-Sentence Reports? Why the Quasi-Market Logic of 'Selling Alternatives to Custody' Fails
}

\author{
Cyrus Tata \\ Professor of Law and Criminal Justice, Centre for Law, Crime and Justice, \\ Strathclyde University Law School, Scotland
}

\begin{abstract}
A central aim of successive generations of penal reformers and governments has been to reduce the use of imprisonment in relatively less serious cases. In their various guises, pre-sentence reports (PSRs) have been a key vehicle to promote non-custodial 'alternatives' to the judicial sentencer. Yet, after decades of pursuing this strategy, a significant reduction in prison sentencing remains elusive. This article suggests that the failure of this policy strategy is, at least in part, rooted in its quasi-market logic. It tends to construct the judicial sentencer as a metaphorical consumer in a penal marketplace, to whom the report writer must convincingly 'sell alternatives' to custody. Applying and developing theories of consumption as a cultural practice, it is proposed that, by its very nature, a consumerist model is bound to fail to deliver penal reduction.
\end{abstract}

Keywords: alternatives to custody; consumer society; consumerism; penal reform; pre-sentence reports (PSRs); probation; sentencing

How should prison sentencing in relatively less serious cases be reduced? Todate, the attempt to reduce the use of 'front-door' prison sentencing in less serious cases has largely relied on a strategy of persuasion through the provision of information about the individual and the viability of 'alternatives to custody' in each case.

This article examines the central role which that policy ascribes to presentence reports (PSRs), which investigate and provide information and assessment to the sentencing courts about convicted individuals so as to inform judicial sentencing. By scrutinising the tendency of policy-orientated thinking to think in quasi-market terms of Reports as a way of exerting influence over 
sentencing, it reveals how sentencers and Report writers have tended to be constructed as, respectively, metaphorical consumers and vendors in a competitive penal marketplace. Employing cultural theories of consumption, the article contends that positioning the judicial sentencer as a quasi-consumer necessarily cannot yield a reduction in the use of prison sentencing. Principally contextualised in the two national jurisdictions of Scotland, and England and Wales, the article raises implications for other jurisdictions, where Reports are being used in indirect efforts to reduce the use of prison sentencing.

The article proceeds as follows: the Section I charts the development of Reports in policy-orientated thinking; the Section II reveals how Reports are conceived of in quasi-market terms, setting up the judicial sentencer as a metaphorical consumer and the Report writer as seller; Section III examines four acute insights from cultural theories of consumption before developing and applying them in the Section IV to the judicial consumption of Reports. Section V sums up key messages and considers the policy implications for efforts at penal reduction.

\section{The Role of Pre-sentence Reports in the Reduction of Prison Sentencing}

In its quest to reduce, or at least moderate, the use of imprisonment as a sentence in relatively less serious cases, policy thinking has largely avoided confronting the assumption that sentencing decisions are 'owned' more or less exclusively by individual members of the judiciary (Ashworth 2015). In common with other western countries, successive governments in Scotland, and England and Wales, and other western countries have not, for instance, sought to assert that the judge should head a multidisciplinary team informing the sentencing process.

Instead, the trope of the individual member of the judiciary (for brevity let us use the universally-recognised term 'judge'), ${ }^{1}$ as possessing sole and sovereign choice of sentence remains largely assumed. Consequently, penal policy thinking hinges on an indirect, subtle strategy of persuasion: alternatives have to be 'sold' to the individual judge. Reports play the central role in this strategy. The general thrust of policy has been to dissuade judicial sentencers from passing prison sentences in relatively less serious cases, by, for example, requiring imprisonment to be a 'last resort', when nothing else is considered suitable by the sentencing judge. This injunction is animated by the requirement that the court should take into account all available information about the circumstances of the offence and offender. ${ }^{2}$ By contextualising the offence and humanising the offender, it is hoped that the sentencing judge will come to see the offending as explicable (though not excusable), so rendering imprisonment a more difficult 
decision. 'The best reports offer an account which enables the court to see an offence as intelligible human action, however deplorable, in the context of the individual circumstances' (Canton and Dominey 2018, p.88).

Thus, albeit in varying ways over time, Reports tend to be expected by reformers to do a subtle job of dissuading judicial sentencers from passing custodial sentences, unless no other sentence is appropriate. By providing apparently neutral facts to the court about the offender 3 prior to sentencing, and about the suitability of different sentencing options, 4 the broad policy role of Reports is to contextualise the offence by individualising and humanising the offender in the eyes of the sentencing judge. This, in turn, should, it is hoped, help to dissuade the sentencing judge from imposing a custodial sentence (for example, Canton and Dominey 2018; Home Office 1961; Mair 2016; Morgan 2003; Morgan and Haines 2007; Raynor 1990; Scottish Executive 2000; Tata et al. 2008; Taylor, Clarke and McArt 2014; Waterhouse 2000).5 Typically, Reports are based on an out-of-courtroom investigation about the person's social and personal circumstances, attitude to the offence and offending, as well as providing information about non-custodial options and their suitability in the individual case. The provision of Reports may be called for by the court at its discretion, or, mandated by law in certain kinds of cases, as has increasingly been the case in both England and Wales and in Scotland. The provision of such Reports (which go by different names across time and jurisdictions), ${ }^{6}$ has become both increasingly prevalent and pivotal to sentence decision making in a range of jurisdictions, including Belgium (for example, Beyens and Scheirs 2010); Canada (for example, Cole and Angus 2003; Hannah-Moffat 2010; Quirouette 2017); Denmark (Wandall 2010); New Zealand (Deane 2000); the USA (for example, Fruchtman and Sigler 1999); England and Wales (for example, Gelsthorpe and Raynor 1995; Jacobson and Hough 2007; Robinson 2017, 2018); Ireland (Carr and Maguire 2017); Australia (for example, Hickey and Spangaro 1995); and Scotland (for example, Tata 2010; Tata et al. 2008). Especially in nominally adversarial systems in the lower and intermediate courts, where guilty pleas obviate the need for an evidentially-contested trial, in considering a custodial sentence, the court will typically hear little or nothing of substance from, or about, the defendant, except through the information garnered through a Report. This, in turn, frequently informs a plea in mitigation by the defence lawyer.

Thus, the opportunity for Reports to influence sentencing decisions and be part of a strategy to reduce the use of incarceration has not been lost on reformminded academics, or, policy officials. ' ... [Reports] should be a part of a strategy of influence in the criminal justice process, and therefore a matter of policy' (Raynor 1990, p.110). '[Reports] provide an invaluable mechanism via which influence can be exerted over sentencing' (Taylor, Clarke and McArt 2014, p.53). The idea is that if judges are better informed about both the individual life and 
circumstances of the person to be sentenced and about the potential advantages of non-custodial penalties, they will be persuaded to pass non-custodial sentences when they would otherwise have been inclined to impose custody. A long tradition of sentencing and probation literature has proposed that if judicial sentencers are provided with high-quality information relevant to sentencing then they will make correspondingly less use of custody (for example, Bateman 2001; Brown and Levy 1998; Creamer 2000; Curran and Chambers 1982; Gelsthorpe and Raynor 1995; Social Work Services Inspectorate 1996; Swain 2005; Taylor, Clarke and McArt 2014). Recently, for example, Birkett (2016) concludes that the failure to reduce the prison sentencing of women is, in large measure, due to the continued lack of confidence in community options for women among many magistrates in community penalties in turn due to a lack of information' (p.509). Provision of high-quality information, 'will allow them to make more informed sentencing decisions and may help to raise levels of confidence in community options' (p.510).

To be relevant to sentencing, the role of Reports is required to be advisory (for example, Canton and Dominey 2018; Hickey and Spangaro 1995; Home Office 1961) - that is, more than mere gathering of facts. '[R]eports are intended to assist sentencing. (Scottish Executive 2004, para. 1.2, italics added). In England and Wales, the Criminal Justice Act 2003 reiterates that Reports are required to assist the court in determining 'the most suitable method of dealing with an offender' (s. 158). In Scotland, Reports 'have a particular role to play in seeking to ensure that offenders are not sentenced to custody for want of information or advice about feasible community-based disposals' (Scottish Executive 2000, para. 1.6). The introduction of National Standards in Scotland, and in England and Wales was intended to improve and standardise the quality of Reports in order 'to reassure judges and the public the service was credible' (Waterhouse 2000, p.56). Indeed, it is considered by governmental policy to be the job of Reports to help sentencers to realise the benefits of non-custodial disposals over custody:

The provision of community based disposal of sufficient quality and quantity will enable sentencers to use them in cases where otherwise they might have imposed a custodial sentence. The overall aim is to create a situation in which it is practicable to use prisons as sparingly as possible through providing community-based disposals which ... have the confidence of the courts ... . (Scottish Executive 2004, para 5, italics added)

It is, however, crucial to a strategy of subtle persuasion, that such objectives are not stated explicitly to judicial sentencers, but, rather, that the skilful assembly of apparently neutral information in the Report should lead the sentencer away 
from the brink of custody. To be more open, it is feared, would lead sentencers to see reports as biased 'with obvious negative consequences for credibility of probation' (Mair 2016, p.77).7

From its origins in, at least (Nellis 2007; Robinson 2017) the last quarter of the 19th Century in the enquiries of police court missionaries in a few courts (Mair 2016; McWilliams 1983; Whitehead 2016, p.179), ${ }^{8}$ the provision of Reports has, over the course of nearly 150 years, grown dramatically (though erratically), in both size and scope in Scotland as well as in England and Wales and other countries (for example, Beyens and Scheirs 2010; Carr and Maguire 2017, p.55; Cole and Angus 2003; Deane 2000; Hickey and Spangaro 1995; Wandall 2010).9 By 1910, the Home Office of England and Wales saw inquiries as normal: 'Reports to the court continued to be used informally and became a routine part of the process ... helping to establish the probation order as a sentencing option', so that by the 1930s such investigation was seen as the foundation of probation (Mair 2016, p.63). The 1961 Streatfield Report recommended widening the role of the Report beyond fitness for probation by providing an informed 'opinion as to the likely effect on the offender of probation or some other form of sentence' (Home Office 1961, p.123, italics added). Such opinion, however, was, and remains, one which cannot be seen to interfere with, or diminish, the trope of exclusive and sovereign judicial choice about sentencing being possessed by the individual member of the judiciary. Rather, the Report writer's role, within the competitive marketplace of sentencing options, is to marshall information skilfully and in a way which leads the judge away from custody and towards the benefits of 'alternatives'.

Both of the two separate national criminal jurisdictions of England and Wales and of Scotland have witnessed a significant overall escalation in the number and incidence of Reports prepared for the courts. The Scottish Executive (2006) reports a 70\% increase since 1996 when around 40,265 written Reports were completed annually in Scotland (Social Work Inspectorate Agency), a figure which was broadly stable in 2010 before falling by around a quarter by 2015-16 (Scottish Government 2017).10 However, this recent reduction must be put in context of an even sharper fall in the number of cases being brought to court, especially in the intermediate Sheriff Court (where around three-quarters of criminal cases are heard and Reports tend to be called for) (Audit Scotland 2015).

Turning to England and Wales, Davies (1974) documents that between 1956 and 1971 there was a fivefold increase in the Magistrates' Courts and a sixfold in the Crown Court of England and Wales that far outstripped the numbers of court cases. By 2009 a total of 230,000 Reports were produced (Mair and Burke 2012, p.184), although by 2017 this figure had dropped to 'approximately 150,000 PSRs' (HM Inspectorate of Probation 2017, p.20). This fall in absolute numbers should be seen, just as in Scotland, in the context of a 
sharp fall in the number of cases being prosecuted through the criminal courts (see also Canton and Dominey 2018). Although this overall trajectory of growth has, just as in Scotland, fluctuated over relatively short periods (Mair 2016; Whitehead 2016), the overall long-term trend may be set to resume. For example, in its new Definitive Guideline on the imposition of community and custodial sentences, the Sentencing Council of England and Wales states that there is a presumption for the court to obtain a Report if it is considering either a custodial (or community) sentence ${ }^{11}$ (Sentencing Council of England and Wales 2016).

\section{Disappointment and Frustration that there has not been Greater Influence}

Despite the dramatic long-term escalation in the number, and incidence, of Reports and the concomitant investment, success remains elusive. Indeed, in many countries although the use of community sanctions has increased dramatically this has not resulted in a net decrease in the use of imprisonment in relatively less serious cases, but rather a decrease in the use of lower tariff sentences (notably financial penalties), and, instead, an increased use of community sanctions alongside rises in the prison population (for example, Abei, Delgrande and Marguet 2015; McNeill and Beyens 2013; Morgan 2003; Phelps 2013). ${ }^{12}$

Thus, on the one hand, there has been a dramatic long-term increase in the provision of Reports, which are specifically tasked with seeking to reduce the use of imprisonment. Yet on the other hand, the increase in the use of imprisonment has barely been arrested, let alone reversed. How can this paradox be explained?

This article argues that the apparent inability of Reports to reduce the use of imprisonment can be located in the very way in which the Report writersentencer relationship is constructed: one based on market metaphors and logic (which long pre-date recent privatisation of probation in England and Wales). Increasingly, the judge is positioned as a quasi-customer or consumer and the Report writer as the seller. This should not be taken literally, however. Sentencing is not shopping in the literal sense. Metaphors enable linkages between associated ideas, so that people visualise, make sense of, and simplify, otherwise impossibly complex information and roles (Wilk 2004). As this article aims to show, market metaphors (for example, selling, buying, competition between options, demand, supply, desire, consumer/customer ${ }^{13}$ sovereignty, rational individual choice, taste, pleasure, satisfaction, waste, novelty etc.), link between abstract categories and to tangible experiences in sentencing. ${ }^{14}$ 
Uncorrected Pre-Publication Version subsequently appearing in The Howard Journal of Crime \& Justice - expected 2018 Vol. 58

\section{Selling and Consuming Reports}

Although the precise forms and historical trajectories are contested, it is widely accepted that market metaphors and logics are becoming increasingly embedded in the ordering of social and economic relations. Increasingly people are coming to see themselves as metaphorical sellers and consumers (for example, Baudrillard 1998, 2001; Bauman 2007; Campbell 2004; Dunn 2008), 'where the logic of the market spills over into other domains of life, challenging and undermining alternative modes of distribution, authority and association' (Loader 1999, p.375). Public services are being marketised, though not necessarily privatised, in the belief that market disciplines will render services more responsive to users. In seeking to encourage participation and responsiveness to service users, market metaphors predominate (rather than, for example, that of collaborative partnership). For example, in the increasingly marketised world of UK higher education (for example, Molesworth, Scullion and Nixon 2011), the identity of student-as-customer is encouraged and 'underpinned by an agenda that seeks to discipline academic life through consumer pressure on higher education' (Ferudi 2011, p.3) Importantly, since the customer is deemed to know best his or her own requirements, the traditional distinction found in the provision of professional services, between the client's subjective wants or desires, as opposed to professional assessment of needs, evaporates (Campbell 2004). In the market model, needs and wants are an unquestioned given: simply posited as 'demand'. For the vendor openly to question consumer demand would border on impertinence, alienating the consumer and so jeopardising present and future sales.

The realm of sentencing is no exception. The sacrosanct trope of individual judicial sovereign choice (discretion) and the requirement of Report writers to persuade that individual of the benefit of their products is easily compatible with market metaphors. ${ }^{15}$ Even before the seemingly sudden privatisation of the probation service in England and Wales in 2015 (for example, Burke and Collett 2016; Robinson 2017, 2018; Robinson, Burke and Millings 2016), some academic writers observed: 'the further emulation of the mechanisms of the market in service delivery ... . [C]onsumer society has already affected the substantive commodification of probation both as a penal product and as a penal process, largely within the state sector' (McCulloch and McNeill 2007, p.224, italics in original).

Writing as the then Chief Inspector of Probation for England and Wales, Rod Morgan (2003) asked the pointed question: 'who does the probation service principally have to satisfy in order that its services continue to be demanded?' 
Who 'buys' probation/community justice services? He identifies that while community justice (probation) does not operate within a true market:

... there is a quasi-market in sentencing options, a quasi-market, which successive governments have, since the 1980 s encouraged for political reasons through the importation of commercial language and devices privatization, contracting out, incentivized decision-making etc - public servants to think in market terms. Thus the talk of customers, products and so on. As far as [the providers of community justice penalties] ${ }^{16}$ are concerned, sentencers are the core users or customers, ${ }^{17}$ or they should be so regarded. (pp.9-10)

'The principal mechanism through which the probation service makes known and offers its services [is through Reports] ... . By these means the service in effect sets out its stall' (pp.9-10). ${ }^{18}$

Morgan points out that demand for Reports and community sanctions is determined principally by the judiciary, and that without its demand probation/community justice would be out of business. ${ }^{19}$ In effect, the judicial sentencer is provided by the State with a voucher to 'spend' on whatever product $\mathrm{s} /$ he chooses from 'the available penal market place'. This though is, as Morgan notes, a quasi-market. For example, sentencers:

are purchasers with no or little concern about the prices and for whom services have no real cost. Another key peculiarity of the sentencers' position is that $\mathrm{s} / \mathrm{he}$ need not necessarily be particularly concerned with the effectiveness or quality of the [community penalty] services s/he consumes ... . (McCulloch and McNeill 2007, p.231, italics in original)

Nonetheless, by so emphasising the sovereignty of consumer choice, the judge is set up as the key consumer of the services set out in Reports. The idea is to make Reports more appealing and responsive to judicial demand.

'Like suppliers, or producers, in any commercial market place, the probation service, steered by its Home Office budget holder, seeks to condition sentencer opinion' (Morgan 2003, p.10). The preparation of Reports is:

the primary vehicle through which the Service represents itself to, and gains credibility with, the courts ... and it is the principal means by which the Service draws offenders into its professional sphere of competence. (Haines and Morgan 2007, p.203)

Reports 'are the primary point of contact with sentencers, who are the main customers for probation work'. Judicial sentencers are 'the main consumers of court reports; it is their decisions that reports are intended to influence. ... and as 
such crucial to the establishment and maintenance of probation credibility' (Mair 2016, pp.61-2, 69, 82). Thus, improving the quality of Reports from the perspective of their principal quasi-consumer might seem to be the critical requirement if prison sentencing is to be reduced.

\section{The Quality of Reports in the Consumerist Logic}

Here it is useful to distinguish between two senses of the meaning of 'quality'. The first we might call 'intrinsic quality'. By this I mean a way of seeing quality as inherent and an end in itself, which can be arrived at through logic and empirical evidence (for example, Gelsthorpe, Raynor and Robinson 2010). The second meaning is one we might call 'extrinsic quality'. This denotes quality as a means to an end: influence in sentencing. The extrinsic meaning of quality dominates policy and practice discourse: quality is seen as synonymous with influence in sentencing. However, almost invariably the meaning of extrinsic quality, and the 'demand' on which it is based, remains unpacked. Following market logic, it is widely said that Reports are not 'good' because they fail to deliver what their consumers want. The challenge is to 'sell' community penalties rather than imprisonment to the sentencer: 'a vehicle for marketing probation' (Mair 2016, pp.74-5). If the sentencer 'buys' the proposed option then the Report is deemed to have influenced the sentencer.

Taylor, Clarke and McArt (2014), for example, examine the reasons why the intensive alternative to custody in England and Wales was not taken up more by magistrates. Their key conclusion is the need to sell alternatives to custody to judicial consumers more persuasively by meeting their concerns. 'Given this significant relationship, the success (or failure) of new community orders lies in effective communication and the judiciary's willingness to concord with proposals' (Taylor, Clarke and McArt 2014, p.53).

A common, yet spurious, measure widely used to measure influence, is the correlation between sentencing decisions recommended by Reports and the actual sentence passed. Variously referred to as 'concurrence', 'concordance', or 'agreement', as if evidencing one-way causality: Reports are assumed to have influenced the sentence outcome they suggested (for example, Cole and Angus 2003, p.302; Deane 2000, p.93; Leifker and Sample 2011; Taylor, Clarke and McArt 2014). The co-incidence of a recommendation and sentencing outcome is conflated with judges 'agreeing with' the recommendation, or elsewhere as 'following' the recommendation (Birkett 2016, p.500). However, the fact that in a formal sense sentence follows a Report does not, in itself, evidence the desired influence (for example, Morgan and Haines 2007; Parker, Sumner and Jarvis 
1989, pp.142-65; Tata et al. 2008). Carter and Wilkins (1967) made the point some 50 years ago: 'Probation officers write their reports and make recommendations anticipating the recommendation the court desires to receive' (p.508, italics added). Nevertheless, the belief that co-relation evidences corresponding influence on the sentencing outcome is surprisingly difficult to dislodge, with some papers (for example, Leifker and Sample 2011) even citing Carter and Wilkins's article in support of the very supposition which they dismantled.

The extrinsic conceptualisation of quality is about responsiveness to the demand of the principal consumers of Reports: judicial sentencers. So the Holy Grail is: 'what do judges want?'; 'What do judges look for in Reports?'; 'How can Reports be made more useful to judges?'; 'How can Reports satisfy or please judicial consumers?'. As in business, the consumer's assessment of quality hinges on her/his expectations. If it falls below the consumer's expectations it will be deemed to be of disappointing quality and vice versa. It is based on the assumption that 'demand' can be apprehended.

Through the logic of the market, the judge, as consumer, is expected to come to make a free, but informed, rational choice between competing sentencing options. By selling non-prison sentences convincingly to the judge through the provision of high-quality information in Reports and by meeting judicial demand, it is believed that $\mathrm{s} / \mathrm{he}$ will come to understand the relative benefits of 'alternatives' to custody in less serious cases.

Yet this strategy is bound to fail. It is bound to fail because ultimately the ability of Reports to satisfy judicial consumer demand is unachievable. Not only is it unachievable, the positioning of the judicial sentencer and Report writer as akin to consumer and seller means that it necessarily must be unachievable. Positioning the judicial sentencer as consumer can only yield a degree of suspicion of, and resistance to, the seller. ${ }^{20}$ Such disenchantment is not only inherent in the very logic of market consumption, but further generated and refracted by notions of judicial independence and inter-professional competition. Allow me to explain by briefly introducing work theorising consumption, especially as a cultural practice.

\section{Thinking about Consumerism and the Consumer Society}

Consumption ${ }^{21}$ is often thought of as an economic transaction, as synonymous with buying; an individual act of rational choice ending at the moment of purchase. ${ }^{22}$ However, in recent decades and inspired by a wider range of disciplines, scholars have developed consumption as more than a monetary and momentary, instrumental transaction. While it is not possible here to provide a 
précis of this rich and diverse field, for the purposes of this article we can highlight four key insights, which will then be applied to, and developed in, the context of Reports.

First, consumption connects the exchange value of material goods with social meaning, identity, and standing. Consumption is a, perhaps now the, preeminent means in everyday social life of reading and communicating group and individual identities (Baudrillard 1998; Campbell 2004). Douglas and Isherwood (1979) conceive of consumption as communication:

We can never explain demand by looking only at the properties of goods. Man needs goods for communicating with others and for making sense of what is going on around him. The two are but one for communication can only be formed in a structured system of meanings. (p.67)

In themselves, goods are neutral: their meaning is not inherent, but 'conferred by human judgements' (Douglas and Isherwood 1979, p.xvii) and those judgments are created through the interrelationships of goods and how they are consumed. Goods are not simply transacted, we think with, and communicate through them, in a way akin to language (Baudrillard 1998).

Second, the study of consumption focuses our attention on the character and patterning of consumer 'demand'. Demand is more than the aggregate of individual rational choices, and desire is not simply a matter of individual whim. What does the study of consumption tell us about those desires and a wider sense of longing, aspiration, and how does that, in turn, link with social and economic structures? How are those desires socially patterned, formed and elicited? How can we explain their change? Desire cannot be understood in isolation from production, but through their intimate and synergistic relationship (for example, Baudrillard 1998, 2001; Storey 2017). Desire is not only reflective of, but itself produces, social (not simply economic), relations (for example, Bauman 2007; Bourdieu 1984).

Third, consumption is an affective activity. At some point and in some way, it is felt by the consumer to be emotionally meaningful: whether it be pleasing, comforting, or indeed, disappointing, dissatisfying, eliciting longing or yearning. While consumption need not be conceived as simple pleasure-seeking hedonism (for example, Galbraith 1978), nor indeed, mainly a dutiful provisioning for loved ones (Miller 2012), it is much more than simple instrumental and rational-cognitive activity. There is some felt aesthetic in the process of consumption (Dunn 2008, pp.77-117).

Fourth, there is a necessary cycle to consumption, which includes a sense of lack or dissatisfaction (Bauman 2007), yearning, longing or desire; excitement, anticipation about the imminent literal or metaphorical purchase, which promises to fill that sense of lack; followed by disappointment, emptiness and 
sense of lack. So the cycle continues. Consumerism demands and accelerates 'an insatiability of desires and insatiability of needs' (Bauman 2007, p.31). Yet the consumer logic means that desire cannot be fulfilled: it is all about the promise of getting there. Bauman (2007) explains that wants must remain, at most, only partly fulfilled:

the desire remains ungratified, more importantly as long as the client is not completely satisfied ... . Consumer society thrives as long as it manages to render the non-satisfaction of its members (and, so in its own terms, their unhappiness) perpetual ... . The yawning gap between promise and delivery is neither a sign of malfunction, nor a side-effect of neglect or the outcome of a mistaken calculation ... [It] is a necessary condition of a properly functioning society of consumers. If the search for fulfilment is to go on and if new promises are to be alluring and catching ... hopes of fulfilment need to be regularly frustrated. (pp.46-7, italics in original)

With these four recurring insights from cultural conceptions of consumption in mind, let us now develop and apply them in thinking about the positioning of Report writer and judge as seller and consumer respectively. Doing so enables us to think afresh about the familiar problems widely thought to obstruct the effectiveness of Reports in influencing sentencing, notably: lack of credibility, lack of realism, non-relevance, inconsistency, and lack of speed.

\section{Consuming Reports}

\section{Producing and Reproducing Judicial Identity}

Consumption is integral to identity. It is not simply reflective of social identities, boundaries and roles; it shapes and reproduces them. '[P]eople create a sense of who they are through what they consume' (Bocock 1993, p.67). Consumption constitutes personality and identity (for example, Boudrillard 1968; Douglas and Isherwood 1979). By consuming, one is continually 'becoming'. Consumption is also an act of status-claiming about our place in the social world. Consumption, and how we 'wear' what we consume, makes us who we are, in the eyes of others and thus to ourselves. In consuming, one is creating and enacting one's identity and drawing out human relationships (including status, boundaries, categories/ontologies, what is sacred, and what is profane). We perform a sense of self-identity through, and with, consumption and this is part of the perpetual process of becoming. Just as 'one is not born a woman, but, rather, becomes one' (de Beauvoir 1984, p.12), so 'identity is performatively constituted by the very "expressions" that are said to be its results' (Butler 1999, p.33). Gendered 
identity, for example, is 'generated only through the necessary repetition of particular acts and gestures ... . A gendered identity is thus the effect of doing gender' (Lloyd 2007, pp.44-8).

Thinking now about the judge as quasi-consumer of Reports, judicial identity is not created nor formed at the moment of appointment. One is not born a judge at the moment of appointment, but rather becomes one. One is continually becoming 'judicial' in the way one communicates verbally and nonverbally, through a stylised repetition of micro-acts (for example, how one comports oneself, gestures etc. (cf. Roach Anleu and Mack 2017; Roach Anleu, Bergman Blix and Mack 2015)). Judicial identity is generated through social interaction. A strong, durable, and delineated, sense of identity cannot be produced through the aggregate of individual abstract cognitive reflections, but through active participation in social activity. This means enactment and performance of identity in which that identity, belief, and belonging, are seen to be retested, revalidated, and thus re-energised. Reports present a way in which judicial (and broader legal) identities and beliefs are seen to be challenged and then revalidated.

Judicial character is performed and regenerated, in part, through the consumption of the Report. Through performance before an audience of the court community (for example, Baum 2006; Tata 2002), ideas about the proper judicial role; the meaning of independence and engagement; the place of the Report writer; professional relationships; and, culpability of the defendant are enacted and demonstrated. Reports are reworked by their consumers, often discussing and negotiating its practical interpretation with defence lawyers (Tata 2010).23 Refracted through the optic of professional inter- and intrarelationships, Reports are crucial to the enactment of meanings about professional roles, identities, and criminal subjects. The contours of judicial and legal identities are delineated and deepened in contradistinction to those of another profession (probation/social work who author Reports). Using this understanding of how Reports are consumed in the representation of judicial roles and inter-professional relations, we can now think afresh about the seemingly intractable problems of influence and quality.

In sentencing, both Report writers and judges can stake legitimate claim to the task of allocating punishment (sentencing). By providing an assessment and evaluation about the individual's character, offending, motivation and the suitability of sentencing options, the Report makes moral evaluation, implicitly challenging territory which is jealously guarded by judiciaries as theirs alone (Ashworth 2015; Tata 2013). Roach Anleu and Mack (2001) neatly identify the phenomenon of: 
professional boundary maintenance: claims that certain practices, tasks, and responsibilities are legitimate legal work and therefore should be performed exclusively by legal personnel ... . To achieve this, legal professionals tend to discredit the work of other occupations by claiming they are less professional or competent and more biased when dealing with 'legal issues'. (p.158)

Thus, judges and lawyers tend to appraise Reports in terms of professional legal values, habits, and practices. The interpretation and consumption of Reports tend to be re-enacted in ways which may deride their objectivity in making moral evaluations about blameworthiness and punishment. Like other professional groups, sentencers tend to regard the evaluations of another 'external' professional group seen as less objective, less realistic, and less rigorous than their own. 'Professions use their abstract knowledge to reduce the work of competitors to a version of their own. This is a basic mechanism of interprofessional competition' (Abbot 1988, p.36).

However, in the quasi-consumerist model, extrinsic quality (quality as influence) is necessarily a shifting target. Judicial consumer demand is not fixed, but variable, shifting, "like wrestling with blancmange"' (Report writer, Tata et al. 2008). Consumerism impels 'an instability of desires and insatiability of needs' (Bauman 2007, p.31). Consumers of Reports are, thus, also producers of ideas of demand, which Report writers, as sellers, are required to pursue, but can never definitively apprehend, nor, completely satisfy. ${ }^{24}$

\section{Consuming Consumerism}

We consume the idea of consumption (Baudrillard 1998; Bauman 2007). Most obviously, (though not only), through advertising, we consume ideas about what is desirable, status-affirming and how to consume (Dunn 2008; Storey 2017). Above all, such messages 'celebrate consumption itself' (Simon 2010, p.262). However, this is not a passive process (Storey 2017, pp.47-62). In the very style, approach and tone of Reports, judicial sentencers consume and reframe messages about their role and relationship as a (sovereign) consumer. In consuming, one is producing and reproducing understandings of proper roles and relationships (for example, Baudrillard 1998, 2001; Bocock 1993).

As quasi-seller, the Report writer is required to adopt a demure posture, restating a recognition of her role as under-labourer and that purchasing choice is the exclusive province of the judge (Halliday et al. 2009). Judicial sentencers tend to note the importance of recognising the sovereign authority of the court, and, for example, that Report writers must not dilute deference to the court by referring to the Report's subject as 'the client'. It is vital that the Report writer 
recognises the court (the judge) as his/her sovereign customer. 'They shouldn't be making "recommendations" (judge, Tata et al. 2008). The very term 'recommendation' is one which Report writers quickly learn may irritate some judicial sentencers: a term which they must learn to rewrite as 'suggestion', 'option' etc., if they are not to look as if they are trying to usurp the judge's sentencing sovereignty. The extent to which Reports can be regarded by judicial consumers as 'influential' is limited by a discourse of judicial and legal ownership of sentencing, and judicial subjectivities about 'independence'. Almost invariably, judicial sentencers strongly resist the idea that their decisions are being influenced by 'strange endogenous elements' with different professional values and perspectives (Beyens and Scheirs 2010, p.32), seen as external to law. 25

\section{a) Encoded messages}

As a result, professional Report writers have to encode their persuasive messages about sentence. Rather than being seen to influence the sentence, through hints, cues and subtle crafting, the sentencer is led deferentially to the suggested outcome. Indeed, among sentencers who recognise this strategy, there may be some enjoyment of the idea that the Report writer defers to the sentencer. 'Ah, but if they let the [judge] he has thought of a sentence, there's psychology in it!' (judge, Tata et al. 2008, p.845). However, by encoding these messages and inviting judges to read between the lines, the intended meaning of Reports is rendered even more liable to be interpreted in ways quite different from that intended by the author.

\section{What do (Judicial) Consumers 'Really' Want?}

\section{a) Individualising and particularising: the desire of difference}

Wearied by mass production and consumption, consumers increasingly seek authenticity and individual differentiation, which signifies higher status (Baudrillard 1998, 2001). In a consumer society, this differentiation is demonstrated by a recognition of the unique and special individual consumer: a customer-experience tailored and responsive to personal preferences and idiosyncrasies.

On the one hand, the summary court process emphasises the machine-like qualities of standardisation, speed, mass production. As the practical custodians of justice, judicial sentencers need to be reassured that they are more than robots on an assembly line. Reports are central to the manifestation of individualisation in two ways. First, Reports, enable judicial sentencers to see themselves as 
Uncorrected Pre-Publication Version subsequently appearing in The Howard Journal of Crime \& Justice - expected 2018 Vol. 58

unique, individual, and sovereign consumers. Second, Reports make apparent the sensitive attention of the sentencing process to the unique individual to be sentenced. Let us briefly consider these two manifestations in turn.

(i) Reports help to generate the individualisation of the judicial consumer

In consumerism, the seller's performed servility means that the consumer is seen as a special and valued individual, to whose idiosyncrasies the service will be gladly adapted (Baudrillard 1998). This is also a sign of elevated status, as if to say: 'not for you, dear customer, identikit mass production, but a very special bespoke, hand-crafted service just for you', thus elevating 'the buyer to the noble, flattering and ego-boosting sovereign-subject, uncontested and uncompromised' (Bauman 2007, p.16). The highest 'quality' Reports in the eye of (most) judicial beholders are those which respond to the 'demand' of personal individual judicial differences. The product is not simply the result of a template, but specially customised to, and by, the individual consumer (Campbell 2005). A central way this intention of the seller is signalled is through a recognition in the Report of inter-sentencer differences.

Realism, credibility and the consumer. A key criticism frequently levelled against Reports is that they often lack credibility and are unrealistic. Sentencers note and let it be known that if, for instance, the suggested proposed sentence is in their eyes 'unrealistic' (for example, Burney 1979; Shapland 1981) and then the credibility of the whole Report is undermined: "It diminishes the validity and the value of the report, if you're getting such an unrealistic suggestion"' (judge, Tata et al. 2008).

However, the ability to apprehend what a 'realistic' sentence would be is undermined both by a lack of transparent sentencing information in similar cases and, second, by an awareness of inter-judge sentencing disparity: what may be realistic to one judge may not be to another (Parker, Sumner and Jarvis 1989, pp.142-65). Indeed, judges are often well aware of individual sentencing reputations to which Report writers (and defence lawyers) are required to adapt accordingly (Tata 2007): 'They know it's [judge] [referring to self] he's not going to wear that!' (Tata et al. 2008, p.842) Report writers are therefore 'almost doomed to fail to live up to [judicial] expectations' (Mair 2016, p.71).

\section{Displaying the individualisation of the standardised case}

The Report plays a central role in the fortification of legal identities, norms and court communities. It enables punishment to be shown to the court as legitimate. Without it, the process in the lower and intermediate courts would be seen to be cursory, dehumanising, concerned only with the mechanical disposal of cases 
without regard for the individual, her voice, or wider context. In the lower and intermediate courts where, typically, a guilty plea obviates the need for a trial, the defendant barely participates. Reports, on which mitigation depends, perform the display of individualisation for the court (for example, that the individual's life in its social context (for example, recognition of socio-economic disadvantage and deprivations), has been thoroughly investigated and $\mathrm{s} / \mathrm{he}$ has been given a voice). The Report is key to enacting and performing the individualisation of the case so that it can then be disposed of by legal professionals in a way which does not query legal ideals, but, indeed, fortifies them and is thus a sense of positive professional identity (Tata 2018). If this may be true, we can hypothesise that recent changes which emphasise speed over depth, displaying standardisation over individualisation (Robinson 2017, 2018) may result, all else being equal, in increased strain among sentencers, defence lawyers, prosecutors, and others. ${ }^{26}$

The 'relevance' of Report information and the celebration of waste and 'information excess'. In and through Reports, judges, lawyers and court actors consume the ideas about professional relations and values (for example, individualisation, individual culpability) which is marked and celebrated through the 'complaint' of excessive information about the individual.

In the consumption of Reports, there is a paradox. On the one hand, fuller Reports are often ridiculed for their 'information excess' (Bauman 2007): 'encyclopaedic' content about golf handicaps, bronchitis as a child etc. (for example, Beyens and Scheirs 2008; Tata 2010; Tata et al. 2008). Yet it would be wrong to imagine that what is derided as 'detail' in these sections is not valued as necessary. Where a Report does not include this 'detail' it is believed to have failed in its task: 'It was a bit lacking, I think. ... It's a bit thin' (post moot interview judge 3, Tata et al. 2008). Similarly, judicial consumers often complain, sometimes almost simultaneously, about Reports being both 'encyclopaedic' (Tata 2010) and 'long-winded' (Jacobson and Hough 2007, p.48) and also about abbreviated Reports being too brief with "too many ticky boxes"' (Tata 2010; Whitehead 2010, p.130). Lawyers, and judges (especially those who are professional lawyers by background), need to feel the weight of this individualised investigation which, in turn, tends to permit such information to be overlooked, or, its import to be neutralised (Tata 2018). Indeed, this apparent contradiction in consumer demand is played out in the restless oscillation between a preference for full, as opposed to abbreviated, Reports (for example, Standard versus Fast delivery PSRs (Canton and Dominey 2018; Whitehead 2008, 2010)).

How can we make sense of this apparent contradiction in consumer demand: wanting yet not wanting 'comprehensive' information about the individual? 
In consumer society, waste is not so much the result of poor planning or inefficiency, but is positively enjoyed. Excess is celebrated: the wasteful consumer feels truly 'alive' (Baudrillard 1998). The perpetual search for new community penalty 'products' and ways of selling them (Reports) so as to persuade the consumer to buy them is inherent in consumerism:

New needs need new commodities; new commodities need new needs and desires; the advent of consumerism augurs the era of 'inbuilt obsolescence' of goods offered on the market and signals a spectacular rise in the waste-disposal industry.

The explicit method of achieving such an effect [perpetual nonsatisfaction of consumers] is to denigrate and devalue consumer products shortly after they have been hyped into the universe of the consumers' desires. (Bauman 2007, pp.31-47)

Governments tend to respond to judicial-consumer complaints about the quality of Reports by marshalling the bureaucratic values of standardisation and speed. Yet, this also tends to result in consumer criticism. Report-writing templates, now being heavily used in England and Wales (Robinson 2018), may come to be seen as copy and paste, tick boxes products. Product novelty is also sought in 'new alternatives' to custody, which judicial consumers may dismiss as another passing fad (Taylor, Clarke and McArt 2014, p.48).

\section{Conclusions}

Sentencing and penal policy presents a paradox. On the one hand, policy documentation accepts as incontrovertible that the decision to imprison (or not) belongs exclusively to the judge. On the other hand, in the context of high and/or sharply rising rates of imprisonment, responsibility for reversing, or at least moderating, the problem of 'prison over-use' (Hough and Jacobson 2008; Tata 2013) is mounted on the shoulders of Report writers who inform and advise the sentencing decision maker. They are, it is thought, very well placed to provide an 'invaluable mechanism via which influence can be exerted over sentencing' (Cole and Angus 2003, p.302; Taylor, Clarke and McArt 2014, p.53).

In policy terms, reduction in prison sentencing, or at least its moderation, hinges on Reports becoming more persuasive. In this way, the need to confront the excessive use of imprisonment in relatively less serious cases is obviated by an indirect strategy in which sentencers come to see for themselves that noncustodial 'alternatives' are more effective and suitable. However, to understand 
the role of Reports in sentencing, we must locate it within a wider understanding of the professional relationship between the Report writer and the sentencer: one which is premised on the market metaphor of a seller-consumer dynamic.

The insatiable desire for 'better' Reports, new formats, new tools, new products to meet consumer demand is generated by the logic of consumerism, which can only lead to disappointment. Fault-finding and inbuilt obsolescence inhere in that logic. In this light, complete extrinsic quality (quality as influence) is necessarily unachievable. Extrinsic quality is not a fixed destination which can one day be arrived at. It cannot be apprehended by a set of flat, non-contingent measures, which can be applied universally (for example, through national standards). Rather, extrinsic quality (in the eyes of its consumers), is necessarily and inescapably amorphous, plural, contradictory shifting and contingent.

This is not to say that attempts at improving the extrinsic quality of Reports are futile. Reports may be improved in the eyes of their consumers and become more influential in the direction intended, but the extent to which this is possible is necessarily and fundamentally confined by the limits of a quasimarket discourse, which positions the Report writer as the seller and judicial sentencer as the sovereign consumer within a penal marketplace. This sellerconsumer relationship means we should expect that the search for the settled extrinsic quality of Reports will be eluded, undermined, teased, and confused. Accordingly, and under such conditions, the idea of extrinsic quality as a fixed and defined destination to which vendors of penal reform can travel, and eventually arrive, may be an illusion.

Conceiving of the judge as the metaphorical consumer in a quasi-marketplace appears to empower the judge. It is a way of demonstrating the judge's apparent non-accountability, freedom and sovereignty: the customer is always right; the customer is king. The job of the seller is to persuade the consumer to buy her/his goods, while the consumer can simply buy elsewhere: notably prison. This consumerist conceptualisation takes for granted and embeds the idea that the judicial sentencer is minded towards prison as the obvious default if nothing else can prove itself. Making prison 'the last resort' may sound progressive, but it simply solidifies it as the backstop if nothing else seems good enough. Repeatedly it is said that judicial sentencers would be willing to use 'alternatives' to prison more, if only those alternatives were shown to them to be more robust and credible. Unless, and until, that happens prison is the only realistic option. If nothing else is sold convincingly to the judge, then it will be prison. Unlike 'alternative' sentences, prison never has to prove itself to the judge. Prison is always assured. It does not have to be sold or marketed. It is the backstop, the default, which is always ready, dependable and available to the judge, reassuring in its familiarity. While the seller has to make her pitch to the consumer, the consumer is not required to explain his or her decision to the seller. Positioning 
the judge as the consumer solidifies the idea, the trope, of him/her as the exclusive sovereign individual chooser: the decision belongs to the judge alone. Thus, the seller must meet the expectations of the consumer - not to do so risks being perceived as naive or unrealistic. Challenging expectations and assumptions can be bad for business. Just as the positioning of the judge as consumer impels resistance to the influence of Reports, it makes achieving Hudson's (2003) injunction that punishment should be carried out in bad conscience' more difficult to realise.

An alternative to framing Reports in sentencing in market terms of producer/seller and consumer is that of (multi-disciplinary) partnership with the judge as head of the team, a relationship explicitly based on mutual professional respect, while, nonetheless, accepting that the judge takes the final decision. ${ }^{27}$ However, to mainstream this idea would require openly discussing the hitherto taboo idea, the cultural judicial trope, that sentencing belongs solely and exclusively to individual judges. ${ }^{28}$

\section{Endnotes}

${ }^{1}$ In different jurisdictions, a member of the judiciary is called different things according to his or her position in the court hierarchy. This can be confusing to those unfamiliar with that terminology, not least because the same term (for example, 'sheriff') means very different things in different countries (for example, Scotland and the USA). Thus, for the purposes of this article and its international readership, one single, umbrella term is used. The term 'judge' is, arguably, the most intuitive term used to refer to a member of the judiciary at any rank (for example, lay magistrates, stipendiary magistrates, justices of the peace, sheriffs, recorders, judicial officers, etc.). In England and Wales, over $95 \%$ of cases are heard by judges called 'lay magistrates', and in Scotland the vast majority are heard by intermediate lawyer-judges called 'sheriffs'. The term 'judicial sentencer' is also similarly used.

2 That imprisonment should be 'the last resort' is widely recommended by reformers worldwide and incorporated in statute, for example, in England and Wales, the Criminal Justice Act 2003, s. 152(2), or in the Criminal Justice and Licensing Act 2010 in Scotland which, in s. 17, imposes a presumption against short custodial sentences 'unless the court considers that no other method of dealing with the person is appropriate' and must state its reasons.

3 Over time and across the world this investigation and reporting to the court has been carried out by different agencies including social work, probation, voluntary organisations and private companies.

4 For instance, the Criminal Justice Act 2003, s. 158, requires that Reports assist the court in determining 'the most suitable method of dealing with an offender'.

5 In some respects, this approach could be seen as an antecedent of 'nudge' policy approaches (for example, Thaler and Sunstein 2008) advocated in neoliberal societies. Through the adaptation of 'choice architecture', this seeks to nudge citizen decision making in a desired direction, rather than 


\section{Uncorrected Pre-Publication Version subsequently appearing in The Howard Journal of Crime \& Justice - expected 2018 Vol. 58}

directly confronting or obstructing it. That said, the parallel has its limits with sentencing policy: judicial sentencers are a (self-consciously) distinct population from the general public, which the 'libertarian paternalism' of nudge theory tends to have in mind. Unlike sentencing policy strategy discussed here, nudge theory's 'libertarian paternalism' seeks to encourage wholesome choices for the individual consumer's own good.

${ }^{6}$ What these reports are or have been called varies (for example, pre-sentence investigation reports, social i/enquiry reports, criminal justice social work reports, court reports, character reports, etc.). Here, for brevity, let us use the generic term 'pre-sentence reports' or simply 'Reports'.

7 Thus, much of the time this argument is expressed in a muted almost coded way: the official emphasis placed on 'effectiveness' in and 'appropriateness' of sentencing decisions (for example, HM Inspectorate of Probation 2017; Home Office 1961). Yet despite the possible punitive drift, the argument (especially in explicit form) for a custodial sentence remains very rare (Gelsthorpe, Raynor and Robinson 2010; HM Inspectorate of Probation 2017).

${ }^{8}$ Fruchtman and Sigler (1999) argue: 'The idea of the pre-sentence investigation report is older than the idea of probation itself' (pp.158-9).

9 While it should be noted that this trajectory has included periods of reduction and an oscillation between shorter and longer, and verbal and written Reports (Robinson 2017, 2018), the overall longterm trend of expansion as a proportion of criminal court cases seems clear.

${ }_{10}$ This overall rise has been uneven and fluctuating. There have been relatively short-lived falls (for example, Whitehead 2008, p.89) only to be followed by further significant increases (see, for example, Mair 2016; Whitehead 2016).

${ }_{11}$ 'Ideally a pre-sentence report should be completed on the same day to avoid adjourning the case' (Sentencing Council 2016, p.8). So, assuming that this is followed, the sharply increasing use of sameday fast delivery reports in England and Wales (Canton and Dominey 2018, p.93; Robinson 2017) may continue.

${ }^{12}$ That there is no clear evidence that Reports have influenced sentencing so as to achieve a reduction, or even moderation, in prison sentencing does not necessarily mean that Reports have had no net impact on sentencing decisions, though the direction of any net impact may be different from that intended by policy (Mair 2016, p.76; Morgan 2003). Indeed, research suggests that Reports are critical to the sentencing process, but that Reports may be interpreted in significantly different ways from that intended by their authors (for example, Beyens and Scheirs 2010; Parker, Sumner and Jarvis 1989; Tata 2010; Tata et al. 2008), as well as serving 'a number of latent purposes' (Carr and Maguire 2017, p.64; see also Tata 2018).

13 While it is possible to delineate differences between the terms 'customer' and 'consumer' in practice they are used interchangeably (Maringe 2011).

14 Furthermore, the passions of consumption may be due to the metaphorical linkages with deeper passions and imperatives (for example, thirst, hunger, taste) (Belk, Ger and Askergaard 1996; Campbell 2004).

15 Likewise, in theorising the consumption of security, Goold, Loader and Thumala (2010) observe how 'consumption is experienced as a realm of autonomy, agency and sovereignty' (p.7).

${ }^{16}$ Writing before privatisation, Morgan referred to 'probation areas'. 


\section{Uncorrected Pre-Publication Version subsequently appearing in The Howard Journal of Crime \& Justice - expected 2018 Vol. 58}

17 Morgan subsequently in the same article argues that 'we should dispense with the language of customers [as] ... the orthodox doctrine is that customers are always right and must be given what they want'.

18 Morgan was not arguing for the further marketisation nor privatisation of probation services in England and Wales. Rather, the article implored readers to recognise the reality with which probation was faced in protecting its future.

19 The recent privatisation in England and Wales of work dealing with low- and medium-risk offenders complicates the business model considerably. Reports continue to be provided by the public National Probation Service, but offenders are supervised and managed by one of 21 private Community Rehabilitation Companies (CRCs). Thus, Report writers may now be arguing for non-custodial penalties and so giving business to the CRCs. How exactly this will play out needs to be the subject of research (Robinson 2017, 2018).

${ }^{20}$ For example, judicial sentencers sometimes complain of ulterior motives in the 'bias' of Reports in rarely proposing imprisonment, which may be connected to attempts to reduce expenditure (Tata $e t$ al. 2008).

${ }^{21}$ Different writers use consumerism, consumer society, consumption, differently. Bauman (2007) for instance refers to 'consumption' as 'primarily a trait and occupation of individual human beings, consumerism is an attribute of society' (p.28, italics in original). Other writers, though, use the term 'consumption' as an attribute of society. In this article I have not sought to prefer one term over another.

22 Marx (1867) prepared key ground for an ontology of the consumer society, exposing the difference between use-value and exchange-value of objects for consumption. Commodities come to be seen fetishistically as having inherent status, independent of the social relations of their production.

${ }^{23}$ This is, of course, variable in practice: while Reports typically form a key role in the defence lawyers' pleas-in-mitigation, not all judicial sentencers always seek to hear from the defence lawyer about it (Tata 2010; Tata et al. 2008). Unlike defence lawyers, prosecuting lawyers in nominally adversarial national jurisdictions (for example, Scotland, England and Wales, Northern Ireland, Republic of Ireland, Canada and Australia), tend to play a relatively passive role in sentencing, especially in presenting and interpreting Reports to the court.

24 Satisfaction levels of the customer are viewed as a more or less unmediated barometer of whether 'demand' is being met. Simple 'surface' surveys (Mair 2016, p.70) of judicial sentencers tend to chart reported satisfaction with Reports (for example, Hickey and Spangaro 1995). However, reported satisfaction in survey responses do not necessarily result in Reports having influence. When research has moved beyond questionnaires to seek to understand how Reports are used in their practical daily context, a more complex and less positive picture tends to be revealed (Beyens and Scheirs 2008; Field and Nelken 2010; Parker, Sumner and Jarvis 1989, pp.142-65; Tata et al. 2008; Taylor, Clarke and McArt 2014; Wandall 2010).

25 In England and Wales, where Report writing in many less serious cases has been delegated to nonprofessionally qualified 'probation service officers' and takes place after much-reduced investigation, the distinctive professional probation voice and values appears to be becoming more muted and thus likely to be seen as challenging, and more aligned to court expectations (Robinson 2017, 2018). 
${ }^{26}$ Although some magistrates have resigned, and defence lawyers withdrawn from legal aid work in recent times, this may or may not be attributable in part to these changes. Research is needed to identify exactly how the changes Robinson charts may be playing out among consumers.

${ }_{27}$ This is not to deny that there are many examples of such multidisciplinary partnerships which operate (often informally) in local court communities and/or in problem-solving courts, but to note that they remain very much the exception.

${ }^{28}$ Acknowledgements: I wish to record my thanks to Gwen Robinson, Mike Nellis, Nicola Carr, and Lol Burke, for reading and commenting on an earlier version of this article. 
Uncorrected Pre-Publication Version subsequently appearing in The Howard Journal of Crime \& Justice - expected 2018 Vol. 58

\section{References}

Abbott, A. (1988) The System of Professions, Chicago, IL.: University of Chicago Press.

Abei, M., Delgrande, N. and Marguet, Y. (2015) 'Have community sanctions and measures widened the net of the European criminal justice systems?', Punishment \& Society, 17(5), 575-97.

Ashworth, A. (2015) Sentencing and Criminal Justice, Cambridge: Cambridge University Press.

Audit Scotland (2015) Efficiency of Prosecuting Cases through the Sheriff Court, Edinburgh:

HM Inspectorate of Probation.

Bateman, T. (2001) 'Custodial sentencing of children: prospects for reversing the tide', Youth Justice, 1(1), 28-39.

Baudrillard, J. (1968) 'The system of objects', in: M. Poster (Ed.) (2001), Jean Baudrillard: Selected Writings, Cambridge: Polity Press.

Baudrillard, J. (1998) The Consumer Society: Myths and Structures, 3rd edn, London: Sage.

Baudrillard, J. (2001) Selected Writings (2nd edn, ed. M. Poster), Cambridge: Polity Press.

Baum, L. (2006) Judges and their Audiences, Princeton, NJ.: Princeton University Press.

Bauman, Z. (2007) Consuming Life, Cambridge: Polity Press.

Belk, R., Ger, G. and Askergaard, S. (1996) 'Metaphors of consumer desire', Advances in Consumer Research, 23, 368-72.

Beyens, K. and Scheirs, V. (2010) 'Encounters of a different kind: social enquiry and sentencing in Belgium', Punishment \& Society, 12(3), 309-28.

Birkett, G. (2016) “We have no awareness of what they actually do": magistrates' knowledge of and confidence in community sentences for women offenders in England and Wales', Criminology \& Criminal Justice, 16(4), 497-512.

Bocock, R. (1993) Consumption, London: Routledge. 
Uncorrected Pre-Publication Version subsequently appearing in The Howard Journal of Crime \& Justice - expected 2018 Vol. 58

Bourdieu, P. (1984) Distinction: A Social Critique of the Judgement of Taste, London: Routledge.

Brown, L. and Levy, L. (1998) Social Work and Criminal Justice. Vol. 4: Sentencer Decision Making, Edinburgh: The Stationery Office.

Burke, L. and Collett, S. (2016) 'Transforming Rehabilitation: organizational bifurcation and the end of probation as we knew it?', Probation Journal, 63(2), 120-35.

Burney, E. (1979) Magistrate, Court and Community, London: Heinemann.

Butler, J. (1999) Gender Trouble, New York: Routledge.

Campbell, C. (2004) 'I shop therefore I know that I am: the metaphysical basis of consumerism', in: K. Ekstrom and H. Brembeck (Eds.), Elusive Consumption, Oxford: Berg.

Campbell, C. (2005) 'The craft consumer', Journal of Consumer Culture, 5(1), 23-42.

Canton, R. and Dominey, J. (2018) Probation, Abingdon: Routledge.

Carr, N. and Maguire, N. (2017) 'Pre-sentence reports and individualised justice: consistency, temporality and contingency', Irish Probation Journal, 14, 52-71.

Carter, R. and Wilkins, L. (1967) 'Some factors in sentencing policy', Journal of Criminal Law, Criminology and Police Science, 58(4), 503-14.

Cole, D. and Angus, G. (2003) 'Using pre-sentence reports to evaluate and respond to risk', Criminal Law Quarterly, 47, 302-64.

Creamer, A. (2000) 'Reporting to the Scottish courts: the quality of social enquiry reports and custody', International Journal of the Sociology of Law, 28, 1-13.

Curran, J. and Chambers, G. (1982) Social Enquiry Reports in Scotland, Edinburgh: Scottish Office.

Davies, M. (1974) 'Social inquiry for the courts: an examination of the current position in England and Wales', British Journal of Criminology, 14, 18-33.

de Beauvoir, S. (1984) The Second Sex, London: Vintage.

Deane, H. (2000) 'The influence of pre-sentence reports on sentencing in a district court in New Zealand', Australian and New Zealand Journal of Criminology, 33(1), 91-106. 
Uncorrected Pre-Publication Version subsequently appearing in The Howard Journal of Crime \& Justice - expected 2018 Vol. 58

Douglas, M. and Isherwood, B. (1979) The World of Goods: Towards an Anthropology of Consumption, London: Routledge.

Dunn, R. (2008) Identifying Consumption: Subjects and Objects in Consumer Society, Philadelphia, PA.: Temple University Press.

Ferudi, F. (2011) 'Introduction to the marketisation of higher education and the student as consumer', in: M. Molesworth, R. Scullion and E. Nixon (Eds.), The Marketisation of Higher Education and the Student as Consumer, London: Routledge.

Field, S. and Nelken, D. (2010) 'Reading and writing youth justice in Italy and (England and) Wales', Punishment \& Society, 12(3), 287-308.

Fruchtman, D. and Sigler, R. (1999) 'Private pre-sentence investigation', Journal of Offender Rehabilitation, 29(3/4), 157-70.

Galbraith, J.K. (1978) The Affluent Society, Boston, MA.: Houghton Mifflin.

Gelsthorpe, L. and Raynor, P. (1995) 'Quality and effectiveness in probation officers' reports to sentencers', British Journal of Criminology, 35, 188-200.

Gelsthorpe, L., Raynor, P. and Robinson, G. (2010) 'Pre-sentence reports in England and Wales: changing discourses of need, risk and quality', in: F. McNeill, P. Raynor and C. Trotter (Eds.), Offender Supervision, Cullompton: Willan.

Goold, B., Loader, I. and Thumala, A. (2010) 'Consuming security? Tools for a sociology of security consumption', Theoretical Criminology, 14(1), 13-30.

Haines, K. and Morgan, R. (2007) 'Services before trial and sentence: achievement, decline and potential', in: L. Gelsthorpe and R. Morgan (Eds.), Handbook of Probation, Cullompton: Willan.

Halliday, S., Burns, N., Hutton, N., McNeill, F. and Tata, C. (2009) 'Street-level bureaucracy, interprofessional relations, and coping mechanisms: a study of criminal justice social workers in the sentencing process, Law \& Policy, 31(4), 405-28.

Hannah-Moffat, K. (2010) 'Re-conceptualizing pre-sentence reports: risk and race', Punishment \& Society, 12(3), 262-86.

Hickey, J. and Spangaro, C. (1995) Judicial Views about Pre-sentence Reports, Sydney, Australia: Judicial Commission of New South Wales, Australia.

HM Inspectorate of Probation (2017) The Work of Probation Services in Court, Manchester: HM Inspectorate of Probation. 
Uncorrected Pre-Publication Version subsequently appearing in The Howard Journal of Crime \& Justice - expected 2018 Vol. 58

Home Office (1961) Report of the Interdepartmental Committee on the Business of the Criminal Courts, London: HMSO.

Hough, M. and Jacobson, J. (2008) Creating a Sentencing Commission for England and Wales: An Opportunity to Address the Prisons Crisis, London: Prison Reform Trust.

Hudson, B. (2003) Understanding Justice, Buckingham: Open University Press.

Jacobson, J. and Hough, M. (2007) Mitigation: The Role of Personal Factors in Sentencing, London: Prison Reform Trust.

Leifker, D. and Sample, L. (2011) 'Probation recommendations and sentences received: the association between the two and the factors that affect recommendations', Criminal Justice Policy Review, 22(4), 494-517.

Lloyd, M. (2007) Judith Butler, Cambridge: Polity Press.

Loader, I. (1999) 'Consumer culture and the commodification of policing and security', Sociology, 33(2), 373-92.

Mair, G. (2016) 'What is the impact of probation in advising sentencing and promoting community sanctions and measures?', in: F. McNeill, I. Durnescu and R. Butter (Eds.), Probation: 12 Essential Questions, London: Springer.

Mair, G. and Burke, L. (2012) Redemption, Rehabilitation and Risk Management, London: Routledge.

Maringe, F. (2011) 'The student as consumer', in: M. Molesworth, R. Scullion and E. Nixon (Eds.), The Marketisation of Higher Education and the Student as Consumer, London: Routledge.

Marx, K. (1867) Capital: A Critique of Political Economy, vol. 1, Moscow, Russia: Progress Publishers.

McCulloch, T. and McNeill, F. (2007) 'Consumer society, commodification and offender management', Criminology \& Criminal Justice, 7(3), 223-42.

McNeill, F. and Beyens, K. (2013) 'Introduction: studying mass supervision', in: F. McNeill and K. Beyens (Eds.), Offender Supervision in Europe, Basingstoke: Palgrave Macmillan.

McWilliams, W. (1983) 'The mission to the English police courts 1876-1936', Howard Journal, 22, 129-47.

Miller, D. (2012) Consumption and its Consequences, Cambridge: Polity Press. 
Uncorrected Pre-Publication Version subsequently appearing in The Howard Journal of Crime \& Justice - expected 2018 Vol. 58

Molesworth, M., Scullion, R. and Nixon, E. (Eds.) (2011) The Marketisation of Higher Education and the Student as Consumer, London: Routledge.

Morgan, R. (2003) 'Thinking about the demand for probation services', Probation Journal, 5O(1), 7-19.

Morgan, R. and Haines, K. (2007) 'Services before trial and sentence', in: L. Gelsthorpe and R. Morgan (Eds.), Handbook of Probation, Cullompton: Willan.

Nellis, M. (2007) 'Humanising justice: the English probation service up to 1972', in: L. Gelsthorpe and R. Morgan (Eds.), Handbook of Probation, Cullompton: Willan.

Parker, H., Sumner, M. and Jarvis, G. (1989) Unmasking the Magistrates, Philadelphia, PA.: Open University Press.

Phelps, M.S. (2013) 'The paradox of probation: community supervision in the age of mass incarceration', Law \& Policy, 35(1-2), 51-80.

Quirouette, M. (2017) 'Community practitioners in criminal courts: risk logics and multiply-disadvantaged individuals', Theoretical Criminology, published online 18 May, DOI: 10.1177/1362480617707951.

Raynor, P. (1990) 'Book review: Social Inquiry Reports by Bottoms and Stelman', British Journal of Criminology, 30, 109-11.

Roach Anleu, S. and Mack, K. (2001) 'Pleading guilty and professional relations in Australia', Justice System Journal, 22, 155-84.

Roach Anleu, S. and Mack, K. (2017) Performing Judicial Authority in the Lower Courts, London: Palgrave.

Roach Anleu, S., Bergman Blix, S. and Mack, K. (2015) 'Researching emotions in courts and the judiciary', Emotion Review, 7(2), 145-50.

Robinson, G. (2017) 'Stand-down and deliver: pre-sentence reports, quality and the new culture of speed', Probation Journal, 64(4), 337-53.

Robinson, G. (2018) 'Transforming probation services in magistrates' courts', Probation Journal, published online 13 May, DOI: 10.1177/0264550518776778.

Robinson, G., Burke, L. and Milling, L. (2016) 'Criminal justice identities in transition: the case of devolved probation services in England and Wales', British Journal of Criminology, 56, 161-78. 
Uncorrected Pre-Publication Version subsequently appearing in The Howard Journal of Crime \& Justice - expected 2018 Vol. 58

Scottish Executive (2000) National Standards for Social Enquiry and Related Reports and Court Based Social Work Services, Edinburgh: Social Work Services Group.

Scottish Executive (2004) National Objectives for Social Work Services in the Criminal Justice System: Standards - Social Enquiry Reports and Associated Court Services, Edinburgh: Scottish Executive.

Scottish Executive (2006) Criminal Justice Social Work Statistics, 2004-05 (Statistical Bulletin, Criminal Justice Series, CrJ/2006/01), Edinburgh: Scottish Executive.

Scottish Government (2017) Criminal Justice Social Work Statistics 2015-16, Edinburgh: Scottish Government.

Sentencing Council of England and Wales (2016) Imposition of Community and Custodial Sentences: Definitive Guideline Effective from 1st February 2017, London: Sentencing Council.

Shapland, J. (1981) Between Conviction and Sentence, London: Routledge and Kegan Paul.

Simon, J. (2010) 'Do these prisons make me look fat? Moderating the USA's consumption of punishment', Theoretical Criminology, 14(3), 257-72.

Social Work Services Inspectorate (1996) Helping the Court Decide: Report of an Inspection of Social Enquiry Reports for the Criminal Courts, London: HMSO

Storey, J. (2017) Theories of Consumption, London: Routledge.

Swain, P. (2005) "No expert should cavil at any questioning": reports and assessments for courts and tribunals', Australian Social Work, 58(1), 44-57.

Tata, C. (2002) 'Accountability for the sentencing decision process: towards a new understanding', in: C. Tata and N. Hutton (Eds.), Sentencing \& Society: International Perspectives, London: Routledge.

Tata, C. (2007) 'Sentencing as craftwork and the binary epistemologies of the discretionary decision process', Social \& Legal Studies, 16(3), 425-47.

Tata, C. (2010) 'A sense of justice: the role of pre-sentence reports in the production (and disruption of guilty pleas', Punishment \& Society, 12(3), 239-61.

Tata, C. (2013) 'The struggle for sentencing reform', in: A. Ashworth and J. Roberts (Eds.), Sentencing Guidelines, Oxford: Oxford University Press. 
Uncorrected Pre-Publication Version subsequently appearing in The Howard Journal of Crime \& Justice - expected 2018 Vol. 58

Tata, C. (2018) 'The genius of "ritual individualisation": sentencing, mitigation and conviction' (paper presented to the Socio-Legal Studies Association Conference, Bristol).

Tata, C., Burns, N., Halliday, S., Hutton, N. and McNeill, F. (2008) 'Advising and assisting the sentencing decision process', British Journal of Criminology, 6, $835-55$.

Taylor, E., Clarke, R. and McArt, D. (2014) 'The intensive alternative to custody: "selling" sentences and satisfying judicial concerns', Probation Journal, 61(1), 44-59.

Thaler, R. and Sunstein, C. (2008) Nudge: Improving Decisions about Health, Wealth, and Happiness, New York: Yale University Press.

Wandall, R. (2010) 'Resisting risk assessment? Pre-sentence reports and individualized sentencing in Denmark', Punishment \& Society, 12(3), 329-47.

Waterhouse, J. (2000) 'The future of Scottish national standards', Probation Journal, 47(1), 56-8.

Whitehead, P. (2008) 'The probation service reporting for duty: court reports and social justice', British Journal of Community Justice, 6(3), 86-96.

Whitehead, P. (2010) Exploring Modern Probation: Social Theory and Organisational Complexity, Bristol: Policy Press.

Whitehead, P. (2016) Transforming Probation: Social Theories and the Criminal Justice System, Bristol: Policy Press.

Wilk, R. (2004) 'Morals and metaphors: the meaning of consumption', in: K. Ekström and H. Brembeck (Eds), Elusive Consumption, Oxford: Berg. 